\title{
The genetic control of sparteine and debrisoquine metabolism in man with new methods of analysing bimodal distributions
}

\author{
D A P EVANS*, D HARMER*, D Y DOWNHAM $\dagger$, E J WHIBLEY*, J R IDLE \\ J RITCHIE $\ddagger$, AND R L SMITH $\ddagger$ \\ From * the Nuffield Unit of Medical Genetics, Department of Medicine and the Department of Statistics \\ and Computational Mathematics, University of Liverpool, Liverpool L69 3BX; and $\$$ the Department of \\ Pharmacology, St Mary's Hospital Medical School, London W2 IPG.
}

SUMmARY Debrisoquine and sparteine tests were carried out in 215 random white British subjects. There is a high degree of correlation between the urinary 'metabolic ratios' of the two drugs. New mathematical techniques have been developed (1) to define phenotypes and (2) to identify the genotypes within the dominant phenotype. The members of 15 families were tested with both debrisoquine and sparteine. The results indicate that persons who are 'poor metabolisers' of sparteine are also 'poor metabolisers' of debrisoquine and are autosomal Mendelian recessives.

A genetic polymorphism has been described for the benzylic 4-hydroxylation metabolism of the postganglionic adrenergic blocking hypotensive drug debrisoquine. Poor metabolisers of the compound were autosomal Mendelian recessives, homozygous for an allele with a frequency estimated at $0 \cdot 30+\mathrm{SE}$ 0.03 in British whites. ${ }^{1}$

A polymorphism has also been described for the metabolism of sparteine, an alkaloid which has been used as an anti-arrhythmic and oxytocic drug. One phenotype with a frequency of 0.05 in the German population was unable to metabolise the compound. The other phenotype produced two substances thought to result from $\mathrm{N}$-oxidation. The limited amount of pedigree information previously available suggested that 'non-metabolisers' might be autosomal recessives, homozygous for an allele with a frequency of $0 \cdot 22 .^{23}$

This paper presents information to show (1) the manner of inheritance of sparteine metabolism, (2) the relationship between the genetic control of 4-hydroxylation of debrisoquine and the metabolism of sparteine, and (3) the use of improved methods for the analysis of bimodal (and trimodal) frequency distributions.

\section{Methods}

The debrisoquine phenotyping test ${ }^{4}$ and the analytical procedure $^{5}$ were carried out as previously described.

Received for publication 10 September 1982.

Accepted for publication 19 February 1983.
The sparteine phenotyping test $t^{2}$ was carried out as follows. Subjects who had fasted overnight ingested a $100 \mathrm{mg}$ capsule of sparteine sulphate. They remained in the fasting state for a further 2 hours thereafter and were then allowed normal food and drink. The urine excreted 11 to 13 hours after drug ingestion was collected for analysis. The analytical procedure ${ }^{3}$ was carried out as described previously. The areas of the gas liquid chromatography peaks for sparteine, 2-dehydrosparteine, and 5-dehydrosparteine were measured. The 'metabolic ratio' was calculated as:

$$
\begin{gathered}
\text { area of sparteine peak } \\
\text { sum of areas of peaks of 2-dehydrosparteine and } \\
\text { 5-dehydrosparteine. }
\end{gathered}
$$

POPULATION SURVEY OF UNRELATED WHITE BRITISH SUBJECTS

A total of 215 healthy unrelated adult subjects (who had given informed consent) were tested with both compounds, with intervals of at least 4 days being allowed between the two tests.

The families studied whose members were tested with the two drugs were obtained by two methods of ascertainment. (1) Some of the families published in a previous report ${ }^{1}$ were studied because they contained a debrisoquine 'poor metaboliser', found in the population survey of unrelated white British adult subjects. (2) Other families were investigated because they contained a proband who was found in the present population sample of unrelated British 
white adult subjects to be a non-metaboliser of sparteine. Selected persons were tested with sparteine because they had been found to be poor metabolisers of debrisoquine in previous surveys.

Complete biological repeat tests were performed in several subjects of special interest, and most of these repeated the tests with both drugs on occasions some months apart.

\section{STATISTICAL METHODS}

Bimodal frequency distributions often indicate the presence of two phenotypes. Many previous pharmacogenetic papers guess the position of the antimode which separates two phenotypes. To rationalise the process it was assumed that the two phenotypes in the present data were normally distributed. Truncated normal distributions were fitted to those observations whose phenotypic status seemed unequivocal; values that were clearly intermediate were omitted. The parameters of the two normal distributions were estimated by the maximum likelihood method and then substituted into the two density functions. The antimode (point of equal density) was then computed. As will be seen below, this method proved successful with the two sets of original data in this paper (and two previously published sets of data).

A separate problem arises in trying to identify genotypic distributions within the dominant phenotype. If the underlying mechanism is assumed to be diallelic, each member of the dominant phenotype belongs either to genotype AA or Aa. Assuming further that the observations for each genotype are normally distributed, we attempted to estimate the means and variances of these two distributions and the mixing probability $\mathbf{P}$ (five parameters in all). Such a superposition of distributions is known as a mixed distribution; Everitt and Hand ${ }^{6}$ review the various methods of estimating the parameters. Difficulties were known to exist in the estimation procedures (see, for example, Murphy and Bolling? ${ }^{7}$ and so it was necessary here to modify an established method.

The specific difficulty to be overcome was that the maximum likelihood equations and the usual iterative process yield solutions that are genetically uninformative. The iterative process identifies one observation as a group (variance $=0$ ) and the remaining observations form the second group.

Using the graphical method of Bhattacharya ${ }^{8}$ rough estimates of the five parameters were determined. A grid was set up over the $\left(\sigma_{1}{ }^{2}, \sigma_{2}{ }^{2}\right)$ plane. Using the usual iterative equations and keeping each pair of $\sigma_{1}^{2}$ and $\sigma_{2}^{2}$ constant, the likelihood was repeatedly maximised with respect to the remaining three parameters. The values of the parameters where the likelihood was an overall maximum were then used.

The calculations for the antimodal point also yielded an estimate of the proportion $r$, say, of recessive homozygotes. The estimates of the proportions of dominant homozygotes and heterozygotes are $(1-r) p$ and $(1-r)(1-p)$, respectively. Let $\left(\mu_{1}, \sigma_{1}{ }^{2}\right),\left(\mu_{2}, \sigma_{2}^{2}\right)$, and $\left(\mu_{3}, \sigma_{3}^{2}\right)$ be the parameters of the distributions of $\mathrm{AA}, \mathrm{Aa}$, and aa genotypes, respectively. Given an observation $x$ the posterior probabilities that it belongs to the $\mathrm{AA}, \mathrm{Aa}$, and aa genotypes are $K(1-r) \operatorname{pg}\left(x ; \mu_{1}, \sigma_{1}^{2}\right), \quad K(1-r)$ $(1-p) g\left(x ; \mu_{2}, \sigma_{2}{ }^{2}\right)$, and $\operatorname{Krg}\left(x ; \mu_{3}, \sigma_{3}{ }^{2}\right)$ respectively, where $\mathrm{K}^{-1}=\operatorname{spg}\left(\mathrm{x} ; \mu_{1}, \sigma_{1}{ }^{2}\right)+\operatorname{sqg}\left(\mathrm{x} ; \mu_{2}, \sigma_{2}{ }^{2}\right)+\mathrm{rg}$ $\left(\mathrm{x} ; \mu_{3}, \sigma_{3}{ }^{2}\right)$ for $\mathrm{s}=1-\mathrm{r}$, and where $\mathrm{g}\left(\mathrm{x} ; \mu, \sigma^{2}\right)$ is the normal density function with mean and variance $\mu$ and $\sigma^{2}$ respectively.

There are two sets of published data which are relevant to the original material published in this paper: firstly, the frequency distribution histogram of $\log _{10}$ sparteine metabolic ratios of 380 random German subjects published by Eichelbaum et $a^{2}$ and, secondly, the debrisoquine data from Evans et al. ${ }^{1}$

The mathematical analyses of these published group frequency data necessitate adaptations of the

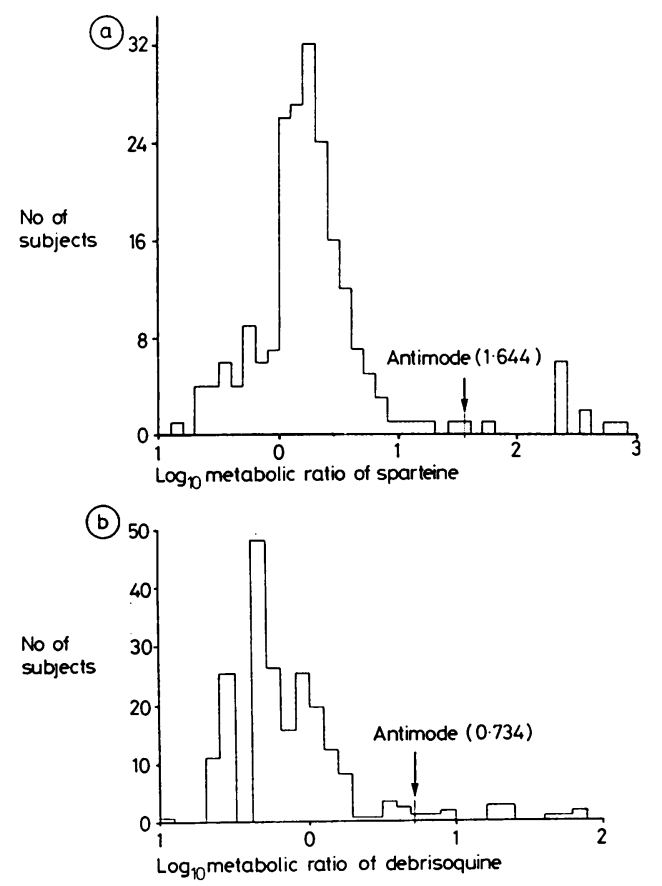

FIG 1 (a) Frequency distribution histogram of $\log _{10}$ metabolic ratio for sparteine in 215 unrelated white British subjects. (b) Frequency distribution histogram of $\log _{10}$ metabolic ratio for debrisoquine in 215 unrelated white British subjects. 
techniques used for our original data which use individual values from all subjects.

\section{Results}

THE GENETICS OF SPARTEINE METABOLISM

The frequency distribution of the $\log _{10}$ metabolic ratio (MR) of the 215 unrelated random white British subjects studied in the present work exhibited a bimodal frequency distribution similar to that previously published ${ }^{2}$ (fig 1 ).

The assessment of phenotypes was not made by an arbitrary division at $\log _{10} \mathrm{MR}=2$ as in a

TABLE 1 Estimated parameters for the two phenotypes.

\begin{tabular}{|c|c|c|c|c|c|c|c|c|c|c|c|c|}
\hline \multirow[t]{2}{*}{ Sample } & \multicolumn{2}{|c|}{$\begin{array}{l}\text { Arbitrarily } \\
\text { chosen } \\
\text { cut-off points }\end{array}$} & \multirow{2}{*}{$\begin{array}{l}\text { No of } \\
\text { points in } \\
\text { interval } \\
\left(C_{1}-C_{2}\right)\end{array}$} & \multicolumn{3}{|c|}{ Dominant } & \multicolumn{3}{|c|}{ Recessive } & \multirow{2}{*}{$\begin{array}{l}\text { Log }_{10} M R \text { values } \\
\text { which divide } \\
\text { data between } \\
\text { phenotypes }\end{array}$} & \multicolumn{2}{|c|}{$\begin{array}{l}\text { Allele frequency } \\
\text { estimates }\end{array}$} \\
\hline & $\left(C_{1}\right)$ & $\left(C_{2}\right)$ & & No & Mean & $S D$ & No & Mean & $S D$ & & $q$ & $p$ \\
\hline $\begin{array}{l}\text { Present debrisoquine data } \\
\text { Present sparteine data } \\
\text { Evans et al }{ }^{1} \text { debrisoquine } \\
\text { Eichelbaum } \text { et } \text { al }^{2} \text { sparteine }\end{array}$ & $\begin{array}{l}0 \cdot 6 \\
1.4 \\
0 \cdot 8 \\
1\end{array}$ & $\begin{array}{l}1 \cdot 12 \\
2 \\
1 \cdot 0 \\
2 \cdot 4\end{array}$ & $\begin{array}{c}6 \\
4 \\
3 \\
26\end{array}$ & $\begin{array}{l}200 \\
202 \\
231 \\
344\end{array}$ & $\begin{array}{l}-0 \cdot 194 \\
0 \cdot 2 \\
-0 \cdot 10 \\
0.036\end{array}$ & $\begin{array}{l}0 \cdot 27 \\
0 \cdot 364 \\
0 \cdot 33 \\
0 \cdot 357\end{array}$ & $\begin{array}{r}9 \\
9 \\
24 \\
10\end{array}$ & $\begin{array}{l}1 \cdot 44 \\
2 \cdot 483 \\
1 \cdot 455 \\
3 \cdot 087\end{array}$ & $\begin{array}{l}0 \cdot 3125 \\
0 \cdot 172 \\
0 \cdot 303 \\
0 \cdot 22\end{array}$ & $\begin{array}{l}0.734 \\
1.644 \\
0.862 \\
1.822\end{array}$ & $\begin{array}{l}0 \cdot 244 \\
0 \cdot 207 \\
0 \cdot 316 \\
0 \cdot 168\end{array}$ & $\begin{array}{l}0.776 \\
0.893 \\
0.684 \\
0.832\end{array}$ \\
\hline
\end{tabular}

TABLE 2 Complete biological repeat tests.

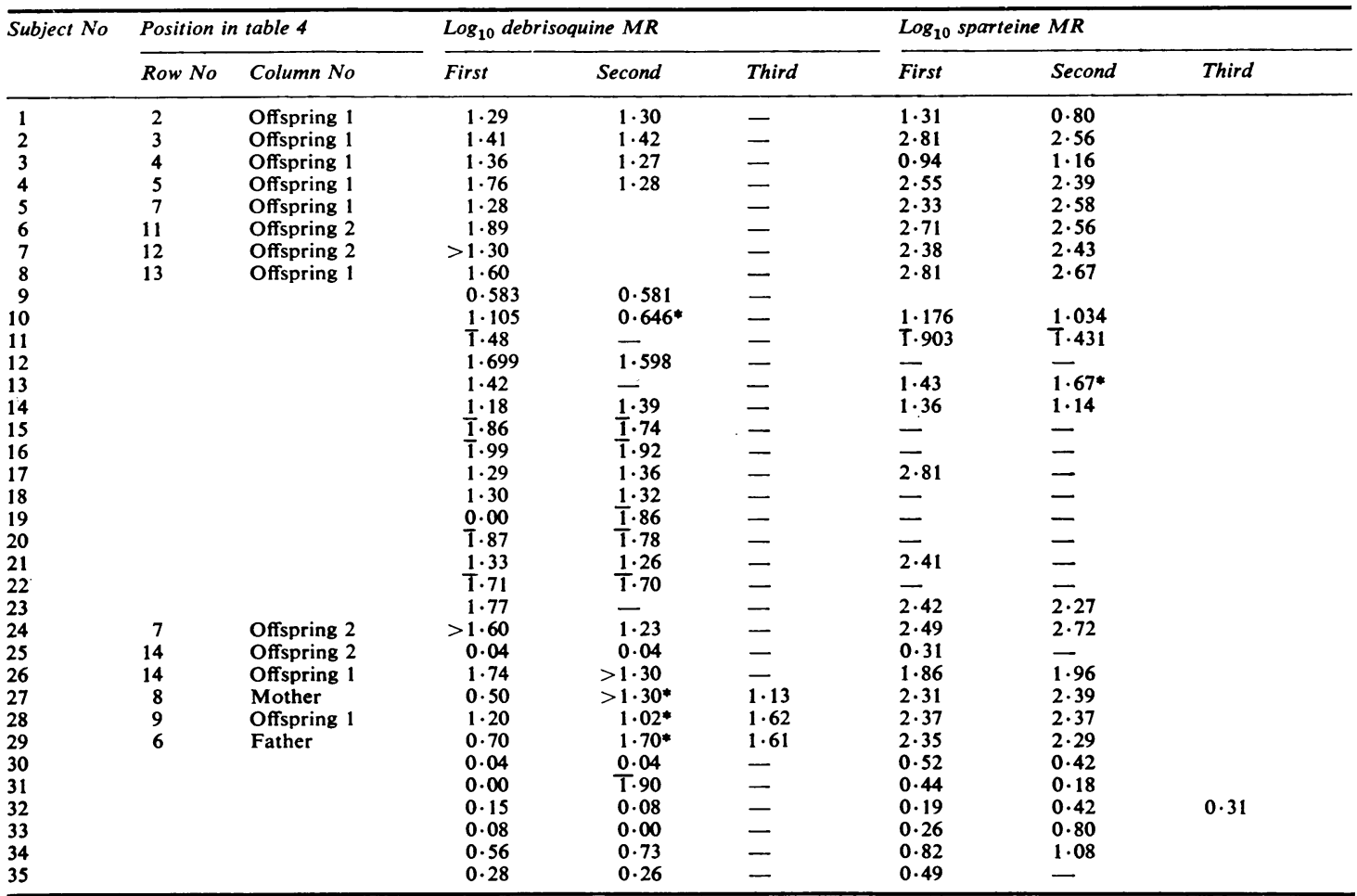

Apparent change of debrisoquine phenotype.

TABLE $3 \log _{10}$ sparteine $M R$ subdivided by age and sex.

\begin{tabular}{|c|c|c|c|c|c|c|c|c|c|c|c|c|c|c|c|c|c|c|c|}
\hline Age & $\begin{array}{l}0.2- \\
0.4\end{array}$ & $\begin{array}{l}0.4- \\
0.6\end{array}$ & $\begin{array}{l}0.6- \\
0.8\end{array}$ & $\begin{array}{l}0 \cdot 8- \\
0\end{array}$ & $\begin{array}{l}0- \\
0.2\end{array}$ & $\begin{array}{l}0.2- \\
0.4\end{array}$ & $\begin{array}{l}0.4- \\
0.6\end{array}$ & $\begin{array}{l}0.6- \\
0.8\end{array}$ & $\begin{array}{l}0.8- \\
1.0\end{array}$ & $\begin{array}{l}1.0 \\
1.2\end{array}$ & $\begin{array}{l}1.2- \\
1.4\end{array}$ & $\begin{array}{l}1.4- \\
1.6\end{array}$ & $\begin{array}{l}1 \cdot 6- \\
1.8\end{array}$ & $\begin{array}{l}1.8- \\
2.0\end{array}$ & $\begin{array}{l}2 \cdot 0 \\
2 \cdot 2\end{array}$ & $\begin{array}{l}2 \cdot 2- \\
2 \cdot 4\end{array}$ & $\begin{array}{l}2.4- \\
2.6\end{array}$ & $\begin{array}{l}2 \cdot 6- \\
2 \cdot 8\end{array}$ & Total \\
\hline $\begin{array}{l}0-25 \\
26-45 \\
46+\end{array}$ & $\begin{array}{l}3 \\
3 \\
1\end{array}$ & $\begin{array}{l}4 \\
6 \\
1\end{array}$ & $\begin{array}{l}5 \\
4 \\
2\end{array}$ & $\begin{array}{l}9 \\
5 \\
-\end{array}$ & $\begin{array}{r}24 \\
20 \\
8\end{array}$ & $\begin{array}{r}29 \\
21 \\
5\end{array}$ & $\begin{array}{r}12 \\
13 \\
2\end{array}$ & $\begin{array}{l}8 \\
3 \\
1\end{array}$ & $\begin{array}{l}5 \\
2 \\
2\end{array}$ & $\frac{2}{-}$ & $\frac{2}{-}$ & $\frac{1}{-}$ & $\begin{array}{l}1 \\
1 \\
-\end{array}$ & - & - & $\begin{array}{l}2 \\
1 \\
3\end{array}$ & $\frac{1}{1}$ & $\begin{array}{l}1 \\
1 \\
-\end{array}$ & $\begin{array}{r}109 \\
80 \\
26\end{array}$ \\
\hline \multicolumn{20}{|l|}{$\overline{\operatorname{Sex}}$} \\
\hline $\begin{array}{l}\text { Females } \\
\text { Males }\end{array}$ & $\begin{array}{l}3 \\
4\end{array}$ & $\begin{array}{l}2 \\
9\end{array}$ & $\begin{array}{l}7 \\
4\end{array}$ & $\begin{array}{l}7 \\
7\end{array}$ & $\begin{array}{l}23 \\
29\end{array}$ & $\begin{array}{l}28 \\
27\end{array}$ & $\begin{array}{l}17 \\
10\end{array}$ & $\begin{array}{l}4 \\
8\end{array}$ & $\begin{array}{l}2 \\
7\end{array}$ & $\begin{array}{l}1 \\
1\end{array}$ & $\overline{2}$ & $\overline{1}$ & 2 & - & - & $\begin{array}{l}2 \\
4\end{array}$ & $\begin{array}{l}1 \\
1\end{array}$ & 1 & $\begin{array}{l}100 \\
115\end{array}$ \\
\hline
\end{tabular}


previous publication, ${ }^{2}$ but by a mathematical assessment. In subjects who had complete biological repeat tests the first value was used in this computation except in subjects 27 and 29 in table 2 for whom the means of triplicates were used.

Using this method the upper mode had a mean of $2.48 \pm$ SD 0.17 , the lower mode had a mean of $0.21 \pm$ SD 0.36 , and the antimode was 1.64 (see table 1).

The repeatability of this phenotyping procedure was assessed by testing the same subjects on different occasions (table 2).

Age and sex were found not to influence the $\log _{10}$ MR of sparteine (table 3).
The pedigree information is shown in table 4 and reveals that:

non-metaboliser male and female offspring can be produced by the mating of two extensive metabolisers;

non-metabolisers can father non-metaboliser sons and daughters;

non-metabolisers can mother non-metaboliser sons;

non-metabolisers of both sexes occur in the same sibship.

The following analysis is based upon the $\overline{0}$ assumptions (1) that the distributions are normal in

TABLE 4 Families studied for the metabolism of debrisoquine and sparteine.

\begin{tabular}{|c|c|c|c|c|c|c|c|c|c|c|c|c|c|c|}
\hline \multirow[t]{2}{*}{ Family No } & \multicolumn{2}{|l|}{ Father } & \multicolumn{2}{|c|}{ Mother } & \multicolumn{2}{|c|}{ Offspring 1} & \multicolumn{2}{|c|}{ Offspring 2} & \multicolumn{2}{|c|}{ Offspring 3} & \multicolumn{2}{|c|}{ Offspring 4} & \multicolumn{2}{|c|}{ Offspring 5} \\
\hline & $\boldsymbol{D}$ & $\boldsymbol{S}$ & $D$ & $S$ & $D$ & $\boldsymbol{S}$ & $D$ & $\boldsymbol{S}$ & $D$ & $\boldsymbol{S}$ & $D$ & $S$ & $D$ & $\boldsymbol{S}$ \\
\hline \multicolumn{15}{|c|}{ A. Families ascertained via poor metaboliser of debrisoquine in previous study' } \\
\hline 1 & $>2 \cdot 29$ & 2.69 & 0.04 & $0: 28$ & $\begin{array}{l}M \\
\stackrel{\uparrow}{M} 1.48\end{array}$ & $2 \cdot 53$ & $M^{1.89}$ & 2.43 & $\mathrm{M}_{1 \cdot 88}$ & $2 \cdot 37$ & & & & \\
\hline 2 & 0.63 & 0.79 & $1 \cdot 00$ & $1 \cdot 88$ & $\begin{array}{r}\uparrow 1.29 \\
1.30\end{array}$ & $\begin{array}{l}1 \cdot 31 \\
0.80\end{array}$ & 0.40 & 0.40 & & & & & & \\
\hline 3 & 0.28 & 0.62 & 0.48 & 0.61 & $\begin{array}{r}\uparrow 1.41 \\
1.42\end{array}$ & $\begin{array}{l}2 \cdot 81 \\
2 \cdot 56\end{array}$ & $M_{1.32}$ & $2 \cdot 60$ & 0.32 & 0.95 & $1 \cdot 84$ & 2.65 & & \\
\hline 4 & 0.72 & 0.81 & 0.04 & 0.14 & $\begin{array}{l}\mathrm{M} \\
\uparrow 1.36 \\
1.27\end{array}$ & $\begin{array}{l}0.94 \\
1.16\end{array}$ & $M_{0.64}$ & 0.63 & $\mathrm{M}_{0.77}$ & $1 \cdot 28$ & & & & \\
\hline 5 & 0.48 & 0.38 & $0 \cdot 34$ & 0.55 & $\begin{array}{r}\uparrow 1.76 \\
1.28\end{array}$ & $\begin{array}{l}2 \cdot 55 \\
2 \cdot 39\end{array}$ & $1 \cdot 26$ & $2 \cdot 38$ & & & & & & \\
\hline
\end{tabular}

B. Families ascertained via poor metaboliser of sparteine discovered in present series of unrelated subjects

\begin{tabular}{|c|c|c|c|c|c|c|c|c|c|c|c|c|}
\hline 6 & $\begin{array}{l}0.70 \\
1.70 \\
1.61\end{array}$ & $\begin{array}{l}\uparrow 2.35 \\
2 \cdot 29\end{array}$ & $\overline{1} .60$ & $\overline{1} .63$ & 0.04 & 0.57 & & & & & & \\
\hline 7 & T.60 & 0.80 & 1.51 & 2.50 & $\begin{array}{l}M_{1.28} \\
-\end{array}$ & $\begin{array}{l}\uparrow 2.33 \\
2.58\end{array}$ & $\begin{array}{l}M \\
>1.60 \\
1.23\end{array}$ & $\begin{array}{l}2.49 \\
2.72\end{array}$ & & & & \\
\hline 8 & & & $\begin{array}{l}0.496 \\
>1.30 \\
1.13\end{array}$ & $\begin{array}{l}\uparrow 2 \cdot 31 \\
2 \cdot 39\end{array}$ & $\mathbf{M}_{0.20}$ & 0.67 & $\overline{1} .78$ & 0.08 & $T \cdot 90$ & 0.33 & & \\
\hline 9 & & & & & $\begin{array}{l}M_{1.20} \\
1.02 \\
1.62\end{array}$ & $\uparrow 2.37$ & 0.59 & 0.98 & & & & \\
\hline 10 & & & & & $M_{1.29}$ & $\uparrow 2.53$ & $M_{1.68}$ & 1.45 & ${ }^{\overline{1} .60}$ & 0.26 & $M_{\overline{1} .85}$ & 0.73 \\
\hline 11 & $\overline{1} \cdot 78$ & 0.13 & - & - & $\overline{1} .95$ & 0.49 & 1.89 & $\begin{array}{l}\uparrow 2.71 \\
2.56\end{array}$ & $\overline{1} \cdot 70$ & 0.40 & & \\
\hline 12 & $\overline{1} .95$ & 0.37 & 0.73 & 0.89 & T.90 & 0.02 & $\stackrel{M}{>1 \cdot 30}$ & $\begin{array}{l}\uparrow 2.38 \\
2.43\end{array}$ & & & & \\
\hline 13 & & & & & $M_{1.60}$ & $\begin{array}{c}\uparrow 2.81 \\
2.67\end{array}$ & $\overline{1} \cdot 70$ & 0.21 & & & & \\
\hline 14 & $\overline{1} .85$ & 0.11 & $\begin{array}{l}\overline{1} .78 \\
1.81\end{array}$ & $\begin{array}{l}0.30 \\
\uparrow 2.35\end{array}$ & $\begin{array}{l}M \\
\uparrow 1.74 \\
>\frac{1}{1} \cdot 30 \\
1.70\end{array}$ & $\begin{array}{l}1.86 \\
\frac{1}{1} .96 \\
1.87\end{array}$ & $\begin{array}{l}M_{0.04} \\
0.04\end{array}$ & 0.31 & & & & \\
\hline
\end{tabular}

* Her sister gave D ī.85 S 0.0128 .

$\mathrm{D}=\log _{10}$ metabolic ratio for debrisoquine.

$\mathbf{S}=\log _{10}$ metabolic ratio for sparteine.

Arrow indicates proband.

$M$ indicates male. 
TABLE 5 Estimates of the different genotypes from the analysis of the mixture of distributions.

\begin{tabular}{|c|c|c|c|c|c|c|c|c|c|c|}
\hline & \multicolumn{3}{|c|}{ Dominant homozygote } & \multicolumn{3}{|l|}{ Heterozygote } & \multirow{2}{*}{$\begin{array}{l}\text { Computed } \\
\text { dominance } \\
\text { using mean } \\
\text { value for } \\
\text { recessive } \\
\text { shown in } \\
\text { table } 2\end{array}$} & \multirow[t]{2}{*}{$\begin{array}{l}\text { Fitted } \\
\text { estimate } \\
\text { of } p=P r \\
\text { (random } \\
\text { gene is } A)\end{array}$} & \multirow[t]{2}{*}{$\begin{array}{l}\text { Predicted } \\
\text { No of } \\
\text { recessive } \\
\text { homozygotes }\end{array}$} & \multirow[t]{2}{*}{$\begin{array}{l}\text { Observed } \\
\text { No }\end{array}$} \\
\hline & Probability & Mean & $S D$ & Probability & Mean & $S D$ & & & & \\
\hline $\begin{array}{l}\text { Present debrisoquine data } \\
\text { Observed mean and } \\
\text { variance for } \\
\text { debrisoquine heterozygotes } \\
\text { in family data } \\
\text { (present experiment) }\end{array}$ & 0.8195 & -0.261 & $0 \cdot 23$ & $0 \cdot 1805$ & $0 \cdot 1313$ & $0 \cdot 35$ & $53 \cdot 87$ & 0.9008 & $2 \cdot 1$ & 14 \\
\hline $\begin{array}{l}\text { Present sparteine data } \\
\text { Eichelbaum } \text { et } \mathrm{al}^{2} \text { sparteine } \\
\text { Observed mean and } \\
\text { variance for } \\
\text { sparteine in heterozygotes } \\
\text { in family data } \\
\text { (present experiment) }\end{array}$ & $\begin{array}{l}0.4756 \\
0.6818\end{array}$ & $\begin{array}{r}0 \cdot 2424 \\
-0.0355\end{array}$ & $\begin{array}{l}0 \cdot 17 \\
0 \cdot 237\end{array}$ & $\begin{array}{l}0 \cdot 5344 \\
0 \cdot 3182\end{array}$ & $\begin{array}{l}0 \cdot 1707 \\
0 \cdot 4868\end{array}$ & $\begin{array}{l}0.48 \\
0.62\end{array}$ & $\begin{array}{r}106 \cdot 40 \\
66 \cdot 55\end{array}$ & $\begin{array}{l}0 \cdot 6403 \\
0 \cdot 8108\end{array}$ & $\begin{array}{l}27 \cdot 8 \\
13 \cdot 6\end{array}$ & $\begin{array}{l}12 \\
14\end{array}$ \\
\hline
\end{tabular}

Note: Evans et al. ${ }^{1}$ Debrisoquine data failed to converge within the relevant ranges of parameters.

TABLE 6 Posterior probabilities for the 1982 debrisoquine data where $\mu_{1}=-0 \cdot 261, \sigma_{1}=0 \cdot 23, \mu_{2}=0 \cdot 1313$, $\sigma_{2}=0.33, \mu_{3}=1.44$, and $\sigma_{3}=0.3125$, and where the genotypic ratios are $p^{2}: 2 p q: q^{2}$ for the two estimates of $p$.

\begin{tabular}{|c|c|c|c|c|c|c|}
\hline \multicolumn{3}{|l|}{$p=0.9$} & \multirow{2}{*}{$\begin{array}{l}\text { Assumed } \\
\text { observation of } \\
\log _{10} M R\end{array}$} & \multicolumn{3}{|l|}{$p=0.78$} \\
\hline $\begin{array}{l}\text { Dominant } \\
\text { homozygote }\end{array}$ & Heterozygote & $\begin{array}{l}\text { Recessive } \\
\text { homozygote }\end{array}$ & & $\begin{array}{l}\text { Dominant } \\
\text { homozygote }\end{array}$ & Heterozygote & $\begin{array}{l}\text { Recessive } \\
\text { homozygote }\end{array}$ \\
\hline 0.9295 & 0.0705 & 0 & -1 & 0.8386 & $0 \cdot 1614$ & 0 \\
\hline 0.9591 & 0.0409 & 0 & -0.5 & 0.9023 & 0.0977 & 0 \\
\hline 0.7859 & $0 \cdot 2141$ & 0 & 0 & 0.5912 & 0.4088 & 0 \\
\hline 0.0481 & 0.9508 & 0.0011 & 0.5 & 0.0195 & 0.9776 & 0.0029 \\
\hline 0 & 0.5896 & 0.4104 & 1 & 0 & $0 \cdot 3614$ & 0.6386 \\
\hline 0 & 0.0032 & 0.9968 & $1 \cdot 5$ & 0 & 0.0013 & 0.9987 \\
\hline 0 & 0 & 1 & $2 \cdot 0$ & 0 & 0 & 1 \\
\hline
\end{tabular}

and (2) that the metabolism is controlled by two alleles at one autosomal locus.

The dominance was computed by a method reported previously ${ }^{1}$ and gave the following results. There were 12 people whose $\log _{10}$ MR exceeded $1 \cdot 644$ and their mean value was $2 \cdot 35$. (Note the close similarity with the computed value of 2.483 , see above.)

Mean value for 18 heterozygotes (from family data) $=0.45=\mathrm{H}$.

Frequency of allele controlling the recessive character

$$
=q=\sqrt{\frac{12}{215}}=1-0 \cdot 24 \text {. }
$$

Frequency of allele controlling the dominant character

$$
=\mathrm{p}=-0.24=0.76 \text {. }
$$

Mean value for dominant homozygotes $=0.07$.

Hence interhomozygous distance $=2 \cdot 28$.

Value of mid-point between homozygotes $=1 \cdot 21$.

So displacement of heterozygote $=0 \cdot 76$, which, expressed as a percentage of distance from midhomozygote point towards the homozygote dominant is

$\frac{0.76}{1 \cdot 14}=66.67 \%$. This is the degree of dominance.

An alternative approach based on the mathematical considerations described yields the mean, variance, and relative frequency for each genotype (table 5). The dominance estimated from the data by this method was $106 \cdot 40 \%$. A value at which the densities of the heterozygotes and the recessives are equal could be computed from these estimates of the parameters. However, a preferable method is to compute the probability that a subject with a given $\log _{10}$ MR value belongs to a given genotype. Some examples are given in table 6.

THE GENETICS OF DEBRISOQUINE METABOLISM Instead of using an arbitrary antimodal value of $\log _{10} \mathrm{MR}=1 \cdot 1$ to separate the phenotypes as was 
done previously, ${ }^{1}$ the data on the 215 random unrelated white subjects were subjected to the mathematical assessment described above. Where subjects had complete biological repeat tests, the first value obtained was used in these computations. The antimode was computed to be 0.734 and the upper mode was computed to have a mean of 1.44 with SD $\mathbf{0} \cdot 28$. Scrutiny of the pedigrees in table 4 in the light of this new definition of phenotypes leads again (on the same criteria as above) to the same conclusion with regard to debrisoquine metabolism, that is, poor metabolisers are Mendelian recessives and extensive metabolisers are Mendelian dominants.

The dominance may be computed as previously described.

Actual mean value for 14 recessives

(defined by the antimode of 0.734 )

from population survey

Mean value for 20 heterozygotes

(from family data)

Frequency of $\mathrm{q}=\sqrt{\frac{14}{215}}=$

0.26 and hence $p$

Computed mean value for dominant homozygote

and interhomozygote distance

Value of mid-homozygote point

So displacement of heterozygote

from this point which

expressed as percentage of distance

from mid-homozygote point towards

$$
\text { the homozygote dominant is } \frac{0 \cdot 30}{0 \cdot 87}=34.48 \% \text {. }
$$

The dominance computed by the alternative method was $53 \cdot 87 \%$.

\section{REPEATABILITY}

Table 2 shows the results of complete biological repeat tests on 35 subjects. Three subjects each performed three debrisoquine tests.

Generally the differences between repeated debrisoquine tests were small, but in some subjects large swings of metabolic ratio were observed. When these few subjects were excluded from consideration repeatability was similar in both phenotypes. This is surprising because the 4-hydroxymetabolite peak in poor metabolisers is much less precisely measurable than in extensive metabolisers, and so the metabolic ratio might vary considerably from time to time. Subjects 10, 27, and 29 underwent an apparent change of phenotype on repeat testing. The variance of repeatability was $\underset{\text { Variance }}{\text { debrisoquine }}=\frac{\sum_{\mathrm{i}=1}^{\mathrm{n}}\left(\mathrm{x}_{\mathrm{i}_{\mathrm{i}}}-\mathrm{x}_{\mathrm{i}_{\mathrm{i}}}\right)^{2}}{2 \mathrm{n}}=0.054$.

For sparteine the situation was similar but no really $\frac{O}{\bar{N}}$ large swings between repeat tests were observed in $\vec{\delta}$ any of the subjects studied. The variance of repeatability was

$$
\text { Variance sparteine }=0 \cdot 032 .
$$

\section{RELATIONSHIP BETWEEN DEBRISOQUINE AND SPARTEINE RESULTS}

Random subjects

For the 215 random subjects this relationship is $\stackrel{0}{O}$ shown in fig 2. Note that to construct this figure, $\dot{\omega}$ mean $\log _{10}$ metabolic ratios of debrisoquine and $\underset{\sim}{\mathrm{N}}$ sparteine repeat results were used. The $\log _{10}$ 을 metabolic ratio of sparteine is plotted on the abscissa (x) and $\log _{10}$ metabolic ratio of debrisoquine is 0 plotted on the ordinate $(\mathrm{y})$. The correlation $\frac{O}{0}$ coefficient is $0 \cdot 81$. The regression line $y=0 \cdot 31+\underset{\varnothing}{\varnothing}$ $0.613 \mathrm{x}$. The coefficient of determination for linear regression $=0.66$. The $95 \%$ confidence limits $\vec{\varnothing}$ (Chatfield, ${ }^{9}$ pp 174 and 177) are shown in the figure. It will be seen that 10 values out of 215 lie a short distance outside these limits.

\section{Family data}

It will be seen that in most instances there is complete correlation between the two polymorphisms, thus agreeing with the view obtained by studying random subjects. However, there are four anomalous subjects: family 2 , offspring 1 ; family 4 , offspring 1 ; family 4 , offspring 3 ; and family 10 , offspring 1 .

The third of these subjects shows a $\log _{10}$ MR of debrisoquine only just above the division point, so in view of the overlap of the phenotypic distributions

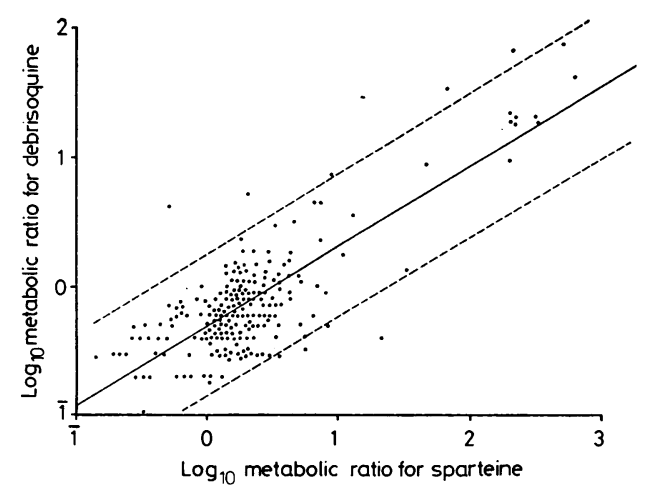

FIG 2 Scattergram of $\log _{10}$ metabolic ratios for sparteine and debrisoquine in 215 unrelated white British subjects. 
and the variability on repeat testing the anomaly could be explained on this basis. Similarly in the fourth subject the $\log _{10}$ MR of sparteine is only a little below the division and so similar considerations might apply. The first and second subjects, however, have repeatedly anomalous values, being extensive metabolisers of sparteine and poor metabolisers of debrisoquine.

\section{Selected subjects}

Note that in table 2 subject 14 is an extensive metaboliser of sparteine but a poor metaboliser of debrisoquine.

\section{PREVIOUSLY PUBLISHED DATA}

The computations described were applied to the sparteine data of Eichelbaum et $a l^{2}$ and the debrisoquine data of Evans et al. ${ }^{1}$ The results are shown in tables 1 and 5 .

\section{Discussion}

In common with many studies the mathematical arguments are based on normal distributions. Because the number of unequivocal recessives is small, the estimates of the mean, variance, and allele frequency obtained from them are necessarily imprecise, and so the computed antimode might be unreliable. However, in table 1 the computed antimodes for both drugs are seen to be similar for different sets of data.

The procedures for identifying the genotypes within the dominant phenotype are again based upon the normality of the underlying distributions. If this assumption is wrong (for example, owing to skewness), the computed estimates can be imprecise. However, the values of $p$ and $q$ computed from the data for dominants alone agree fairly well with the values of $p$ and $q$ computed from the data from both phenotypes (tables 1 and 5).

The dominance calculations using the method given in the paper of Evans et al ${ }^{1}$ must be considered to give only approximate answers. This is because each estimated parameter used in the computation has a sizeable standard error, and dominance depends on the arbitrary scale of the measurements. Also, heterozygotes derived from families ascertained only by means of recessive probands are considered to be representative of all heterozygotes in the population, and this may not necessarily be true.

Some success has been achieved in separating the distributions of the three genotypes: the present set of data for debrisoquine and the sparteine data of Eichelbaum et $\mathrm{al}^{2}$ converge to biologically acceptable solutions as illustrated in fig 3 and table 5 . However, the numerical process for resolving the dominant

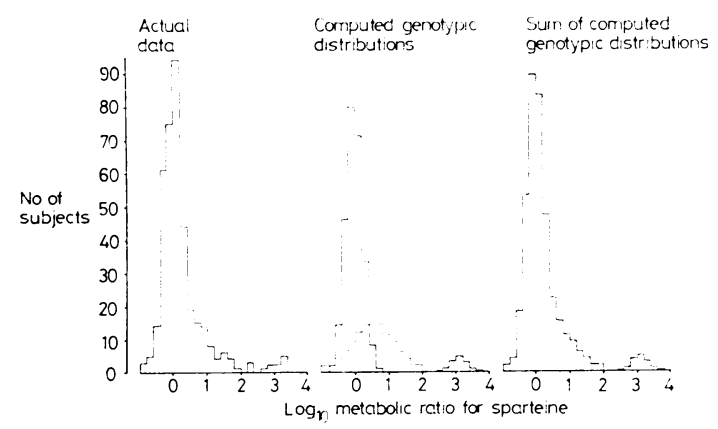

FIG 3 Frequency distribution histograms of $\log _{10}$ metabolic ratio for sparteine in 380 German subjects. (Left) Actual data of Eichelbaum et al ${ }^{2}$ redrawn. (Centre) The individual genotypic distributions computed from these data. (Right) Sum of the computed genotypic distributions.

genotypes does not converge for the present set of sparteine data or for the debrisoquine data of Evans et al. ${ }^{1}$ When a process does not converge to an acceptable solution, several possibilities must be considered. If the means are close together then there are perhaps too few observations. Alternatively, the two allelic models might not fully describe the data, although this seems unlikely in this study as convergence has already occurred for debrisoquine and sparteine data.

In the interpretation of the results of the procedure to identify genotypes within the dominant phenotype, the geneticist must decide which is the homozygote and which the heterozygote. The assumption is usually made that over-dominance is absent. However, for the present sparteine data such an interpretation leads to a further difficulty, viz a much larger variance in the dominant homozygotes than in the heterozygotes.

Because of the difficulties already noted, the computed dominance values in table 5 are likely to be imprecise: for example, the computed dominance for the two sets of sparteine data are widely different.

In estimating the parameters of the phenotypes using the present results, the raw data were used. The parameter estimates are computed faster with grouped frequencies than with raw data; the analysis of the published data ${ }^{12}$ was performed on grouped data. However, in separating the dominant genotypes, grouped frequencies were always used because rounding errors arose when the raw data were used.

Some judgement is necessary in deciding upon the truncation points when estimating the parameters 
of the phenotypes. The phenotype of any observation not in the interval between the truncation points is assumed to be unequivocal. However, the modes of the two distributions must be clearly outside the interval between the truncation points and so the selected interval cannot be too wide.

Despite the difficulties encountered in the computations on the present sparteine and 1980 debrisoquine data, ${ }^{1}$ it was considered that the two alleles of major effect at one autosomal locus were sufficient to explain most of the observed data on the metabolism of both drugs. Furthermore, it seemed unnecessary, in view of the family data, to assume more complicated models. In particular, the close correlation between the metabolic ratios in random subjects supported this view.

Among family members and selected subjects there were four persons with anomalous results. Possible explanations which may be considered are as follows: (1) 'error' of phenotyping method; (2) long term environmental effects; (3) influence of modifier alleles (alleles of minor effect), for example, acting to magnify what are normally minor pathways of metabolism; and (4) linked loci for alleles of major effect. If the metabolism of the two drugs were controlled by alleles of major effect at two closely linked loci, with a high degree of 'linkage disequilibrium' (gametic association), then it would be possible to explain rare anomalous persons. There are, however, two arguments against this suggestion. Firstly, some subjects can change apparent phenotype on re-testing with debrisoquine and, secondly, a selection pressure of unprecedented degree would be required to maintain such a disequilibrium. No firm conclusions with regard to these four possibilities can be drawn from the present data.

While the present work has been in progress certain relevant publications have appeared. Eichelbaum et al ${ }^{10}$ have phenotyped 29 EM and nine PM subjects with both debrisoquine and sparteine. In each subject the phenotype as determined with both drugs was the same. Of course, it is clear that these subjects did not represent a random population sample and so must have been selected. In one subject the debrisoquine metabolic ratio was $6 \cdot 2$, but on re-analysing the same specimen of urine, a ratio of 33 was obtained. A complete biological repeat gave a ratio of 62 .

Otton et al $^{11}$ published an enzymological study in which human liver specimens metabolised sparteine in vitro. Dixon plots revealed that the metabolism of sparteine was competitively inhibited by debrisoquine. Two liver samples were studied but the phenotypes of the two donors were unknown. So while this work suggests strongly that the same enzyme deals with both drugs in the liver, it does not prove that the enzymic mechanism is the same for both drugs in both phenotypes.

The enzymic basis of the polymorphism has been investigated by Davies et $a l^{12}$ and Kahn et al. ${ }^{13}$ These workers determined the in vivo phenotype of subjects from whom liver biopsy material was available. Total hepatic P-450 content was shown not to differ between the phenotypes. Extensive metabolisers were able to form 25 to $50 \mathrm{pmol}$ 4-hydroxydebrisoquine/mg microsomal protein/ minute, whereas one poor metaboliser produced none, so it was suggested that a highly specific form of NADPH requiring hepatic P-450 may be missing in poor metabolisers.

These very elegant enzymological observations suggest most strongly that the same mechanisms are responsible for the oxidation of both sparteine and debrisoquine in the human liver. However, they are based on very few persons (especially poor metabolisers) and so do not rule out the possibility of non-concordance in an occasional subject.

\section{References}

1 Evans DAP, Mahgoub A, Sloan TP, Idle JR, Smith RL. A family and population study of the genetic polymorphism of debrisoquine oxidation in a white British population. J Med Genet 1980;17:102-5.

2 Eichelbaum M, Spannbrucker N, Dengler HJ. A probable genetic defect of the metabolism of sparteine. In: Gorrod JW, ed. Biological oxidation of nitrogen. Amsterdam: Elsevier/North Holland, 1978:113-8.

${ }^{3}$ Eichelbaum M, Spannbrucker N, Steincke B, Dengler HJ. Defective $\mathrm{N}$-oxidation of sparteine in man: a new pharmacogenetic defect. Eur J Clin Pharmacol 1979;16: 183-7.

4 Mahgoub A, Idle JR, Dring LG, Lancaster R, Smith RL. Polymorphic hydroxylation of debrisoquine in man. Lancet 1977; ii:584-6.

5 Idle JR, Mahgoub A, Angelo MM, Dring LG, Lancaster R, Smith RL. The metabolism of ${ }^{14} \mathrm{C}$ debrisoquine in man. Br J Clin Pharmacol 1979;7:256-66.

6 Everitt BS, Hand DJ. Finite mixture distributions. London: Chapman and Hall, 1981.

7 Murphy EA, Bolling DR. Testing of single locus hypotheses where there is incomplete separation of the phenotypes. Am J Hum Genet 1967;19:322-34.

8 Bhattacharya CG. A simple method of resolution of a distribution into Gaussian components. Biometrics 1967; 23:115-35.

9 Chatfield C. Statistics for technology. A course in applied statistics. 2nd ed. London: Chapman and Hall, 1978.

${ }^{10}$ Eichelbaum M, Bertilsson L, Säwe J, Zekorn C. Polymorphic oxidation of sparteine and debrisoquine: related pharmacogenetic entities. Clin Pharmacol Ther 1982;31: 184-6.

11 Otton SV, Inaba T, Mahon WA, Kalow W. In vitro metabolism of sparteine by human liver: competitive ,

(n)

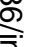


inhibition by debrisoquine. Can J Physiol Pharmacol $1982 ; 60: 102-5$.

12 Davies DS, Kahn GC, Murray S, Brodie MJ, Boobis AR. Evidence for an enzymic defect in the 4-hydroxylation of debrisoquine by human liver. Br J Clin Pharmacol 1981; $11: 89-91$.

13 Kahn GC, Boobis AR, Murray S, Brodie MJ, Davies DS. Assay and characterisation of debrisoquine - hydroxylase activity of microsomal fractions of human liver. Br J Clin Pharmacol 1982;13:637-45.

Correspondence and requests for reprints to Professor D A Price Evans, Nuffield Unit of Medical Genetics, Department of Medicine, University of Liverpool, PO Box 147, Liverpool L69 3BX. 